Gut, 1965, 6, 279

\title{
Malignant Zollinger-Ellison syndrome in a Bantu woman with a prolonged remission after gastric radiotherapy
}

\author{
S. BANK, I. N. MARKS, R. SEALY, J. H. LOUW, AND W. SILBER \\ From the Gastro-intestinal Service and Departments of Medicine, Radiotherapy, \\ and Surgery, Groote Schuur Hospital, Observatory, Cape Town, South Africa
}

EDITORIAL SYNOPSIS A striking remission of symptoms is recorded following radiotherapy directed to the stomach in a case of the Zollinger-Ellison syndrome. It is suggested that previous failure with this method may have resulted from insufficient dosage. The histological similarity of carcinoid and pancreatic ulcerogenic tumours and their differential diagnosis is discussed.

Considerable advances have been made in the recognition of the clinical features and in the understanding of the pathogenesis of the ZollingerEllison syndrome during the nine years that have elapsed since the condition was first described (Zollinger and Ellison, 1955). The disease is characterized by the presence of a non-beta cell tumour of the pancreas associated with gross acid hypersecretion, intractable peptic ulceration, and, not uncommonly, with severe diarrhoea. The acid hypersecretion is now known to be due to gastrin or a gastrin-like substance elaborated by the tumour tissue (Grossman, Tracy, and Gregory, 1961).

The mortality of the disease remains high. A review of 138 cases of the syndrome reported to date reveals an overall mortality of $58 \%$, with postoperative deaths accounting for more than half of this figure. The hazard of surgery was particularly great in patients subjected to repeated operations for recurrent jejunal ulceration, and no doubt prompted a few workers to examine the effect of gastric radiotherapy in reducing acid hypersecretion in such patients. The published results of radiotherapy, however, have not been encouraging (Zollinger and Ellison, 1955; Oberhelman, Nelsen, Johnson, and Dragstedt, 1961; Case records of Massachusetts General Hospital, 1960; Oberhelman, Nelsen, and Dragstedt, 1958; MacKenzie and Norvell, 1960).

The purpose of the present paper is to show that gastric radiotherapy may indeed be effective in inducing a prolonged remission in patients with the Zollinger-Ellison syndrome and to stress the value of the augmented histamine test in the diagnosis of the condition. In addition, the stimulating effect of the patient's serum concentrate on acid secretion in the dog will be briefly presented.

\section{CASE REPORT}

The patient, a South African Bantu woman 22 years of age, was admitted as an emergency on 28 August 1962 after a brisk haematemesis. She gave a story of periodic dyspepsia for five years manifesting as epigastric pain and post-prandial vomiting; nocturnal pain was a feature. Two weeks before admission she developed a severe recurrence of dyspepsia complicated by pain radiating through to the back and, on the day of admission, by the vomiting of 1 to 2 pints of blood. For six years she had had irregular, scanty periods and dysmenorrhoea associated, more recently, with nausea, vomiting, nervousness, night sweats, and loss of weight and prompted a gynaecological examination for possible pelvic tuberculosis two months previously. An endometrial biopsy and a radiograph of the chest showed no abnormality. The haemoglobin was 16.5 g. $\%$ and E.S.R. $31 \mathrm{~mm} . / \mathrm{hr}$. (Westergren) at the time. There was no family history of peptic ulceration.

Examination revealed a small, rather thin woman in slight shock. Her pulse rate was regular at 96 per minute and her blood pressure was $110 / 70 \mathrm{~mm}$. of $\mathrm{Hg}$. The abdomen was distended and diffusely tender. The liver appeared to be normal in size and the spleen was not palpable. The haemoglobin was $8 \mathrm{~g} . \%$ and the E.S.R. $115 \mathrm{~mm}$./hr (Westergren). The white cell count was 7,000 per c.mm. and the differential count was normal; platelets were plentiful on the peripheral smear. The blood urea was elevated at $172 \mathrm{mg} . \%$. The serum albumin was $4.4 \mathrm{~g} . \%$, serum globulin 2.0 g. $\%$, serum bilirubin 0.4 mg. $\%$, and the prothrombin index $100 \%$.

Blood transfusion and intensive ulcer therapy was 
started on admission. She continued to bleed, however, and an emergency barium meal on 3 September revealed a duodenal ulcer with surrounding spasm and oedema. The patient had by this time received 10 pints of blood, and emergency surgery was therefore arranged on the grounds of continued bleeding.

At operation the duodenal ulcer was found to be penetrating into Hartman's pouch, and in addition, numerous hard, white nodules were noted in the liver, and firm glands were seen along the lesser curvature of the stomach. Blood was present in the small and large bowel. A polya type gastrectomy with Hofmeister valve was carried out and biopsies were taken from the liver nodule and lymph node.

RESECTED STOMACH The resected specimen measured $16 \mathrm{~cm}$. along the greater curve and $4 \mathrm{~cm}$. on the lesser curve. The stomach was thickened $(0.2 \mathrm{~cm}$. in thickness) and oedematous and showed several superficial linear mucosal ulcers, the largest measuring $1 \mathrm{~cm}$. in length.

RESECTED LIVER NODULE AND LYMPH NODE The macroscopic and histological features were identical in both specimens. The cut surface showed a homogeneous dead white opaque appearance. Histologically there were multiple rounded islands of cells with a fairly uniform appearance. The cells had distinct nuclei but ill-defined borders, and a tendency to acinar formation was noted. A few clusters of cells were intravascular. The cells failed to stain with silver stains. Despite this, the features were thought to be those of metastatic carcinoid tumour. The lymph nodes showed, in addition, a marked desmoplastic reaction. The histology, reviewed after acid secretory studies pointed to a diagnosis of the Zollinger-Ellison syndrome, was later considered to be that of the ZollingerEllison syndrome rather than of carcinoid.

POST-OPERATIVE COURSE The immediate post-operative course was uneventful, but ulcer symptoms recurred just before her scheduled discharge two weeks after her operation. This, coupled with information on the postoperative acid secretory data and the reviewed histology, suggested the development of a jejunal ulcer. She was discharged from hospital on intensive antacid and anticholinergic therapy, but continued to be troubled by dyspeptic symptoms. She was readmitted to hospital, again as an emergency, two months following operation with a tentative diagnosis of a perforated jejunal ulcer. An episode of very severe abdominal pain associated with distension, epigastric tenderness and guarding, absent bowel sounds and clinical evidence of free fluid in the abdomen favoured the diagnosis, but a straight radiograph of the abdomen failed to reveal air under the diaphragm. The possibility of an exacerbation of ulcer dyspepsia, with ascites an incidental finding due to peritoneal metastases, was considered as an alternative diagnosis. This possibility, though excluded by the subsequent course of events, was a factor which prompted the institution of conservative rather than surgical treatment at the time. She improved on gastric suction, intravenous fluid replacement, and antibiotics, and a barium meal carried out a few days later revealed a large jejunal ulcer and the presence of free fluid in the abdomen. Reluctance to carry out a total gastrectomy in the face of possible ascites due to multiple metastases prompted us to consider gastric freezing or gastric radiotherapy as an alternative method of parietal cell ablation. Gastric radiotherapy was begun on 19 December. Irradiation of the left upper quadrant through $15 \times 15 \mathrm{~cm}$. anterior and posterior fields was given over 21 days. The total dose was 2,640 skin dose to 2,244 central dose at $250 \mathrm{KV}$, $3.5 \mathrm{~mm}$. CuHVL $50 \mathrm{~cm}$. FSD. Symptomatic improvement began soon after starting treatment and symptoms disappeared within a few days of completing the course of radiotherapy. The symptomatic remission has persisted throughout the 21 months of follow-up and, in contrast, she has been having regular menses during this time. Body weight increased during the first few months after radiotherapy and has since remained normal for her age and height. No form of medical treatment has been necessary during the past 21 months. The liver has not increased in size on clinical or radiological examination during this period, and a recent barium meal showed no evidence of jejunal ulceration.

Investigations other than acid secretory studies included the following: urinary 5-hydroxy indole acetic acid (before and following radiotherapy) was normal; the haemoglobin was maintained at $13 \mathrm{~g} . \%$ and the E.S.R. has not exceeded $11 \mathrm{~mm}$./hr. (Westergren); repeated investigations for polyendocrinopathy including skull radiograph, urinary ketosteroids, urinary F.S.H. and serum calcium, phosphorus, and alkaline phosphatase were normal. Pancreatic function tests were carried out at the time when gastric achlorhydria after maximal histamine stimulation had already occurred, with the end of the collecting tube in the efferent loop and a second tube at the stoma. After secretin and pancreozymin stimulation the 80 -minute volume was $80 \mathrm{ml}$., bicarbonate concentration $32 \mathrm{mEq} . / 1$; and amylase concentration 5.23 units $/ \mathrm{ml}$. (Pimstone units). The provocative amylase and lipase test was negative. These results suggested pancreatic insufficiency but biliary-pancreatic pooling of juices in the afferent loop could not be excluded. Glucose tolerance was normal. Serum $B_{12}$ estimations were within the normal range 18 months after radiotherapy and jejunal biopsy was normal. Radioactive and chemical faecal fat excretion and $\mathrm{CO}^{60} \mathrm{~B}_{12}$ absorption showed no abnormality. Hepatic function was consistently unimpaired as evidenced by normal liver function tests, serum protein, alkaline phosphatase, serum electrophoresis, and bromsulphthalein excretion tests. Three $I^{131}$ Rose-Bengal hepatic scintiscans were carried out at six-monthly intervals with identical results; an area of decreased uptake of the isotope demonstrated in the lateral apical segment of the right lobe on each occasion was interpreted as being due to metastases in this area. There has been no increase in the 'silent' area over the 18-month period.

RESULTS OF GASTRIC ACID SECRETORY STUDIES BEFORE AND AFTER RADIOTHERAPY

The augmented histamine test, carried out on the eighth postoperative day, revealed massive basal hypersecretion which was, in fact, slightly greater than the response to 
maximal histamine stimulation (Table I). The magnitude of the latter suggested that the patient was a strong candidate for subsequent jejunal ulceration and, moreover, the ratio of basal to post-histamine responses was considered to be diagnostic of the Zollinger-Ellison syndrome. The result also prompted a review of the histology.

\section{TABLE I}

RESULTS OF AUGMENTED HISTAMINE TESTS

\begin{tabular}{lrcc} 
& Date & $\begin{array}{l}\text { Basal Acid } \\
\text { Output } \\
\text { (mEq. total } \\
\text { acid/hr.) }\end{array}$ & $\begin{array}{l}\text { Post-histamine } \\
\text { Response } \\
\text { (mEq. total } \\
\text { acid/hr.) }\end{array}$ \\
\hline Before radiotherapy & 11.9 .1962 & $24 \cdot 5$ & $24 \cdot 2$ \\
During radiotherapy & 19.12 .1962 & $26 \cdot 0$ & $16 \cdot 7$ \\
After radiotherapy & 9.1 .1963 & $15 \cdot 6$ & $15 \cdot 3$ \\
& 16.1 .1963 & $6 \cdot 0$ & $9 \cdot 7$ \\
& 24.1 .1963 & $2 \cdot 3$ & $1 \cdot 8$ \\
& 13.3 .1963 & $1 \cdot 4$ & $1 \cdot 3$ \\
& 18.4 .1963 & 0 & 0.9 \\
15.5 .1963 & 0 & 0 \\
19.6 .1963 & 0 & $0 \cdot 1$ \\
24.7 .1963 & 0 & $0 \cdot 1$ \\
9.10 .1963 & $0 \cdot 1$ & $0 \cdot 1$ \\
27.11 .1963 & $0 \cdot 1$ & $0 \cdot 4$ \\
23.12 .1963 & $0 \cdot 1$ & 0 \\
24.2 .1964 & 0 & 0 \\
27.4 .1964 & 0 & 0 \\
25.5 .1964 & $0 \cdot 1$ & $0 \cdot 1$
\end{tabular}

The effect of anticholinergic drugs on the basal secretion was investigated on four occasions; Probanthine, $30 \mathrm{mg}$. administered intramuscularly, was employed in two of the tests and Nacton (poldine methyl methosulphate), $5 \mathrm{mg}$. administered intravenously, in a further two. Basal secretion was reduced after both preparations, but the magnitude of the reduction was considerably less than that found in patients with jejunal ulceration unassociated with the Zollinger-Ellison syndrome. Probanthine reduced basal secretion by $38 \%$ and $44 \%$ of the original value on the two occasions, and Nacton reduced basal secretion by $12 \%$ in the first and by $45 \%$ in the second test (Fig. 1, Table II).

\section{TABLE II}

EFFECT OF ANTICHOLINERGIC DRUGS ON BASAL SECRETION

\begin{tabular}{ll} 
Date & $\begin{array}{l}\text { Basal Acid Output } \\
\text { (mEq. total acid/hr.) }\end{array}$ \\
\hline Before After & $\%$ Reduction
\end{tabular}

Probanthine

$\begin{array}{llll}\begin{array}{l}\text { Probanthine } \\ \text { 14. } 9.62\end{array} & 23 \cdot 8 & 13 \cdot 9 & 38 \\ \text { 18. } 9.62 & 21 \cdot 8 & 12 \cdot 2 & 44 \\ \text { Nacton } & & & \\ 1.10 .62 & 25 \cdot 8 & 22 \cdot 8 & 12 \\ 6.10 .62 & 22 \cdot 8 & 13 \cdot 4 & 45\end{array}$

The results of serial augmented histamine tests carried out before, during, and after gastric radiotherapy, are presented in Table $I$. A reduction in acid secretion was apparent during the course of radiotherapy, and secretion diminished progressively over the next few months. Virtual
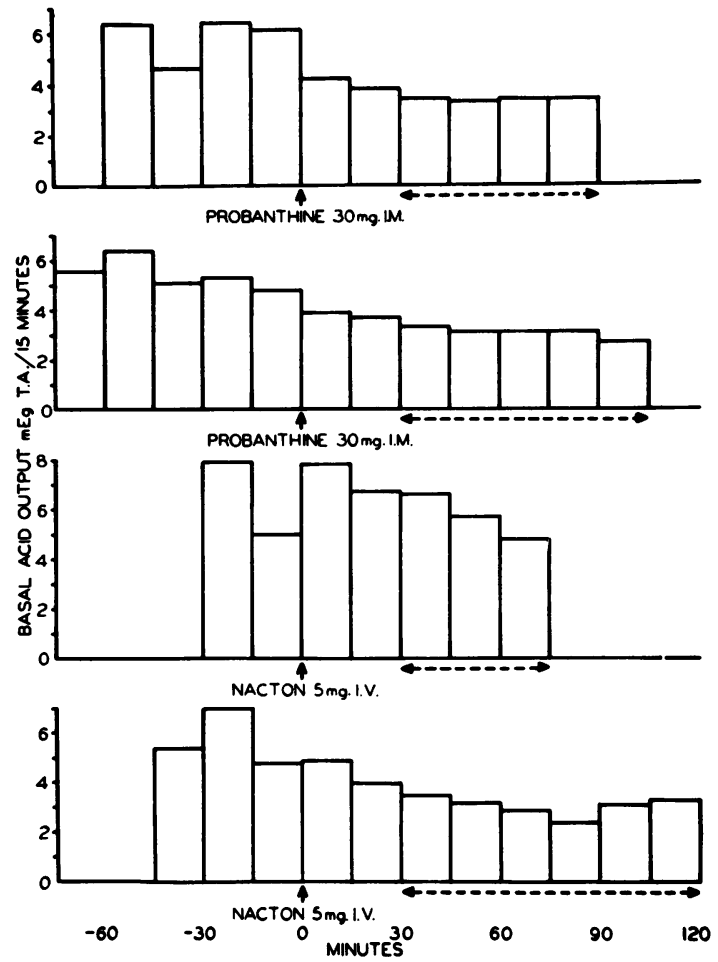

FIG. 1. Effect of Probanthine and Nacton on basal acid secretion in a patient with the Zollinger-Ellison syndrome. - . - - Data used in calculating acid output/hour following anticholinergic injection.

achlorhydria became established four months after the conclusion of the course of radiotherapy, and her gastric secretory status thereafter remained more or less unchanged until last tested in May 1964.

A gastric biopsy carried out in January 1964 revealed that the surface epithelium was almost completely replaced by undifferentiated cuboidal or columnar cells with atrophy and partial fibrous replacement of the glands in the deeper layers. Dilatation and elongation of the foveolae of the glands were present and the cellular population of the lamina propria was increased with an infiltration of polymorphonuclear leucocytes and eosinophils. Many of the latter appeared to be in a stage of active migration through the walls of the glands.

\section{EXPERIMENTAL STUDIES}

Serum, $30 \mathrm{ml}$., was obtained from the patient and $30 \mathrm{ml}$. from each of two control subjects with duodenal ulceration. Each of the three samples of sera were pervaporated to a volume of $5 \mathrm{ml}$. The serum concentrates were injected intravenously into a trained mongrel dog with a previously prepared denervated Heidenhain pouch equipped with a glass cannula. The dog had been trained for a period of three months during which time the pouch remained achlorhydric under basal condition. Fifteen-minute collections of gastric juice were obtained 

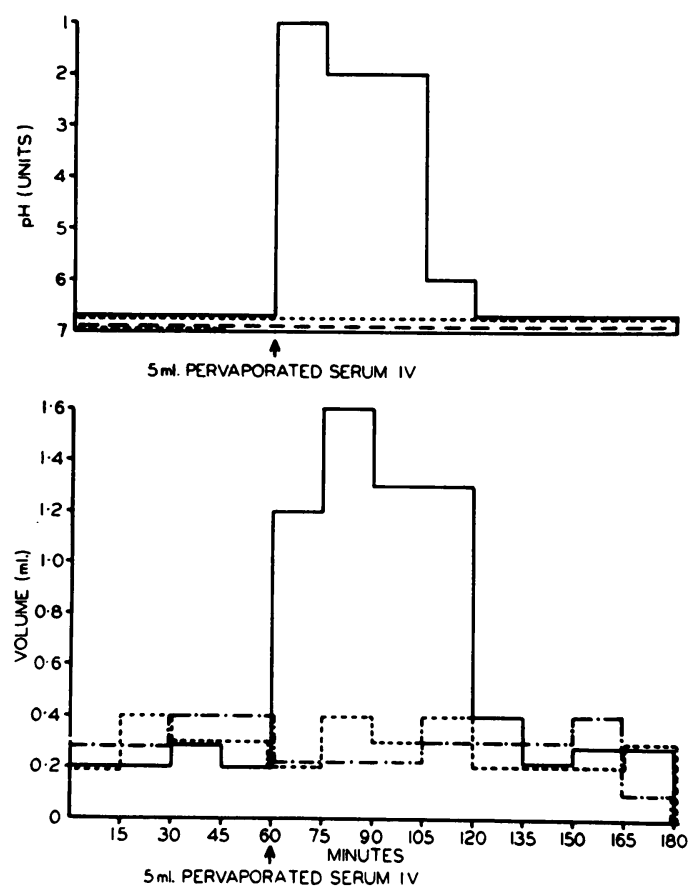

FIG. 2. Effect of $5 \mathrm{ml}$. of intravenous pervaporated serum obtained from the patient and two controls with duodenal ulcer on the volume secretion and $\mathrm{pH}$ of a Heidenhain pouch preparation.

___ patient's serum

..... . . $\}$ control sera

from the pouch for one hour before and two hours after the injection of the sera; the volume and $p \mathrm{H}$ of each collection was measured.

Figure 2 shows the results obtained using the sera from the two controls and from the patient. The basal secretion of 0.2 to $0.4 \mathrm{ml}$. per 15 minutes and $p \mathrm{H} 7$ remained unchanged for a two-hour period after the intravenous injection of the concentrated sera from the two control subjects. After injection of the patient's serum an increased volume of secretion $(1.6 \mathrm{ml}$. per 15 minutes) and acidity $(p \mathrm{H} 1.0)$ was recorded, the effect persisting for about one hour.

An increased incidence of ulceration or a decrease in the time required for the development of gastric ulceration in the Shay rat could not be demonstrated after the intraperitoneal injection of $5 \mathrm{ml}$. of the patient's serum.

\section{DISCUSSION}

In a previous publication (Marks, Selzer, Louw, and Bank, 1961) we have commented on the rarity of peptic ulceration in Bantu females and described the occurrence of the Zollinger-Ellison syndrome in such a subject. The diagnosis in the latter was established by means of the augmented histamine test, histology of the tumour, and assay of the primary and metastases for a gastrin or gastrin-like substance. The finding of multiple rounded deposits in the liver in the present case, another Bantu woman operated on for duodenal ulceration, thus alerted us to the possibility of the Zollinger-Ellison syndrome. The initial histological diagnosis of a carcinoid in this patient appeared to cast doubt on this possibility but review of the histology prompted by the result of the augmented histamine test revealed that the appearance of the tumour was in fact identical with that seen in our previous case of the Zollinger-Ellison syndrome.

The microscopic resemblance between ulcerogenic pancreatic tumours and carcinoid is well recognized (Zollinger and Craig, 1960). Furthermore, both types of tumour have a tendency to progress very slowly, even when frankly malignant. This is exemplified by a patient reported by Zollinger, Elliot, Endahl, Grant, Goswitz, and Taft (1962), who remained well and underwent a successful pregnancy seven years after total gastrectomy for a malignant ulcerogenic tumour of the pancreas and by the patient reported in the present paper who remained well 21 months after gastric radiotherapy despite the presence of widespread glandular and hepatic metastases noted before the course of radiotherapy. The diagnostic difficulty between the two tumours may be further complicated by $(a)$ the affinity of the ulcerogenic tumour for silver stains in some patients (Mieher, Hartsock, Goekas, Ballard, and Frame, 1962; Sanchez and Sommers, 1960), and, conversely, by the lack of silver staining potential in the odd patient with a carcinoid; $(b)$ the association between ulcerogenic tumour and carcinoid present in the same patient (Gerber and Shields, 1960; Williams and Celestin, 1962); (c) the allegedly high incidence of peptic ulceration in patients with metastatic carcinoid disease (MacDonald, 1956; Horsley and Golden, 1957; Lemmer, 1942); and (d) the occasional presence of hyperserotoninuria in patients with ulcerogenic pancreatic tumours, particularly those in whom steatorrhoea is the dominant clinical feature (Espiner and Beaven, 1962). Despite the foregoing, however, we believe that the histological features of an ulcerogenic tumour of the pancreas are sufficiently characteristic to permit a correct diagnosis in the vast majority of cases, and that the correct diagnosis should virtually always be possible if the histological features are considered in conjunction with the clinical story and the acid secretory data derived from the augmented histamine test.

The diagnosis of Zollinger-Ellison syndrome in the present case hinged largely on the result of the augmented histamine test. The post-histamine 
response of $24 \cdot 2 \mathrm{mEq} . / \mathrm{hr}$. confirmed the radiological impression of a jejunal ulcer, but this, coupled with the basal secretion value of $24.5 \mathrm{mEq} . / \mathrm{hr}$., pointed to the jejunal ulcer being a manifestation of the Zollinger-Ellison syndrome. The histological diagnosis of argentaffin-negative carcinoid was then reviewed in favour of ulcerogenic tumour of the pancreas. The result of the test thus offered very strong support for our view regarding its diagnostic value in the Zollinger-Ellison syndrome (Marks, Selzer, Louw, and Bank, 1961; Marks, 1961; Marks, Bank, Louw, and Van Embden, 1962; Marks, Bank, Moshal, and Louw, 1963). Available evidence suggests that gastric hypersecretion associated with a basal secretion: post-histamine response ratio approximating $100 \%$ is virtually diagnostic, and that a ratio greater than $60 \%$ is strongly suggestive of the condition. Ratios between 40 and $60 \%$ should be regarded with suspicion; the test should be repeated and, if surgery is undertaken, careful inspection of the pancreas and peri-pancreatic tissues carried out to exclude an ulcerogenic tumour. Ratios of 40 to $60 \%$ or more have occasionally been encountered in patients shortly after duodenal ulcer perforation and, even more rarely, in patients with simple duodenal ulceration (Bank, Marks, and Moshal, 1964).

It is of interest that Burge, Gill, and Lewis (1964), while conceding that 'acid studies may be helpful in the diagnosis of the Zollinger-Ellison syndrome', regard such studies as unnecessary 'if the pancreas is routinely palpated at operation'. Simple palpation of the pancreas for adenoma is notoriously fallacious and it is well-known that small tumours may be missed by the most expert surgeon unless the tail, body, and head of the pancreas are properly mobilized to permit of inspection and palpation of both anterior and posterior surfaces. Indeed, if no tumour can be found even after mobilization of the main part of the pancreas the uncinate process should be withdrawn from behind the mesenteric vessel and examined before the possibility of a tumour can be excluded. It hardly seems justified to undertake such a laborious procedure on every patient subjected to surgery for duodenal ulcer when a lead as to the advisability of pancreatic exploration may be obtained by means of the augmented histamine test.

Few studies have been carried out on the effect of anticholinergic drugs on basal secretion in patients with a histologically proved Zollinger-Ellison syndrome (Shay, Chey, Koide, and Burnett, 1962; Angervall, Dotevall, Lehmann, and Norberg, 1963; Chvojka, 1960). The data do, however, suggest that anticholinergics may exert a less marked inhibitory effect in such patients than in those with simple peptic ulceration. This is supported by the findings in the present case in which basal secretion was reduced by only 38 to $44 \%$ following $30 \mathrm{mg}$. probanthine administered intramuscularly and by a mere 12 to $45 \%$ following $5.0 \mathrm{mg}$. intravenous poldine methyl methosulphate (Nacton). Similar tests carried out in patients with simple jejunal ulceration following partial gastrectomy characteristically show a striking suppression of basal secretion, usually of the order of 70 to $100 \%$. Although more studies are required, it would appear that the finding of a poor response to anticholinergics in a patient with marked basal hypersecretion should heighten the suspicion that an ulcerogenic tumour may exist, particularly in patients deprived of antral influences following partial gastrectomy.

The development of jejunal ulceration within a few weeks of partial gastrectomy in a patient known to have a Zollinger-Ellison syndrome with hepatic and lymph node metastases posed a difficult problem in management. This was further complicated by a presumed perforation of the jejunal ulcer which occurred while the patient was on intensive antacid and anticholinergic therapy. The possibility of malignant ascites on the one hand and the high mortality for total gastrectomy following previous gastric surgery in this condition (Zollinger et al., 1962) on the other hand prompted us to temporise with a course of gastric radiotherapy.

The gratifying response to gastric radiotherapy in the present case contrasted with the indifferent results observed in eight other patients with the Zollinger-Ellison syndrome submitted to this form of treatment (Table III). Gastric radiotherapy failed to influence acid secretion appreciably in any of the patients so tested. Only two of the eight appeared to show any symptomatic improvement and in both recurrent ulceration developed within two months of completing radiotherapy. Our patient, on the other hand, showed a progressive diminution in acid secretion after commencing radiotherapy and became achlorhydric within four months. Radiotherapy was also followed by a complete clinical remission, and she remains achlorhydric and free of symptoms 21 months later. The failure of previous workers to induce achlorhydria or a satisfactory remission may have been due, in part at least, to the smaller dose of radiotherapy employed by them. Although an individual susceptibility of the mucosa to irradiation exists, Ricketts, Palmer, Kirsner, and Hamann (1948) recommended 1,600 to 2,500 r as the most effective dose in the treatment of uncomplicated duodenal ulceration. The available data suggest that a higher dosage level may be required in the treatment of the Zollinger-Ellison syndrome and that radiotherapy in such patients should not be 
TABLE III

RESULTS OF RADIOTHERAPY IN CASES FROM THE LITERATURE

\begin{tabular}{|c|c|c|c|c|c|c|c|}
\hline \multirow[t]{2}{*}{ Case } & \multirow[t]{2}{*}{ Operations } & \multirow{2}{*}{$\begin{array}{l}X \text {-ray Therapy } \\
(r .)\end{array}$} & \multicolumn{2}{|c|}{ Pre-x-ray Acids } & \multicolumn{2}{|c|}{ Post-x-ray Acids } & \multirow[t]{2}{*}{ Remission (mth.) } \\
\hline & & & $\begin{array}{l}\text { Volume } \\
(\mathrm{ml} .)\end{array}$ & Acidity & $\begin{array}{l}\text { Volume } \\
(m l .)\end{array}$ & Acidity & \\
\hline Zollinger and Ellison (1955) & $\begin{array}{l}1 \text { Radical gastrectomy } \\
\text { and fundusectomy } \\
2 \text { Subdiaphragmatic } \\
\text { vagotomy }\end{array}$ & 2,000 & 2,000 & $\begin{array}{l}32 \text { (free } \\
\text { acid) }\end{array}$ & 1,350 & $\begin{array}{l}81-90 \\
\text { (free acid) }\end{array}$ & $\begin{array}{l}\text { None: radiation } \\
\text { chondritis, oeso- } \\
\text { phageal stricture }\end{array}$ \\
\hline Oberhelman ot al. (1958) & $\begin{array}{l}1 \text { Partial gastrectomy } \\
2 \text { Vagotomy } \\
3 \text { Repair fistula and } \\
\text { gastric resection } \\
4 \text { Resection of body } \\
\text { and tail of pancreas }\end{array}$ & 1,600 & & $\begin{array}{l}52(? \text { free } \\
\text { acid) }\end{array}$ & & $\begin{array}{l}11 \text { (? free } \\
\text { acid) }\end{array}$ & $\begin{array}{l}\text { Abdominal fistula } \\
\text { closed } \\
\text { Recurrence after two } \\
\text { months }\end{array}$ \\
\hline Oberhelman et al. (1958) & $\begin{array}{l}1 \text { Partial gastrectomy } \\
2 \text { Vagotomy }\end{array}$ & 1,600 & & $\begin{array}{l}35 \text { (free } \\
\text { acid } \\
12 \mathrm{hr} \text { ) } \\
14 \cdot 7 \text { (free } \\
\text { acid } 1 \mathrm{hr} \text {.) }\end{array}$ & & $\begin{array}{l}110 \text { (free } \\
\text { acid } \\
12 \mathrm{hr} \text {.) } \\
10 \cdot 1 \text { (free } \\
\text { acid } 1 \mathrm{hr} \text {.) }\end{array}$ & None \\
\hline Oberhelman et al. (1958) & $\begin{array}{l}1 \text { Vagotomy and } \\
\text { gastroenterostomy }\end{array}$ & $?$ & & $\begin{array}{l}31 \text { (free } \\
\text { acid } \\
12 \mathrm{hr} . \text { ) }\end{array}$ & & $\begin{array}{l}94 \text { (free } \\
\text { acid } \\
12 \mathrm{hr} \text {.) }\end{array}$ & $\begin{array}{l}\text { None; ulcer showed } \\
\text { healing }\end{array}$ \\
\hline Oberhelman et al. (1961) & $\begin{array}{l}1 \text { Closure of perforation } \\
\text { of jejunum }\end{array}$ & 1,600 & & $\begin{array}{l}150(12 \mathrm{hr} .) \\
45(1 \mathrm{hr} .)\end{array}$ & & $\begin{array}{l}66(12 \mathrm{hr} .) \\
45(1 \mathrm{hr} .)\end{array}$ & None \\
\hline $\begin{array}{l}\text { MacKenzie and Norvell(1960) } \\
\text { MacKenzie and Norvell (1960) }\end{array}$ & $\begin{array}{l}1 \text { Partial gastrectomy } \\
1 \text { Perforated jejunal } \\
\text { ulcer resected } \\
2 \text { Perforated jejunal } \\
\text { ulcer resected }\end{array}$ & $\begin{array}{l}? \\
?\end{array}$ & - & $\begin{array}{l}\overline{120} \\
\mathrm{mEq} . / 1 .\end{array}$ & - & - & $\begin{array}{l}\text { None } \\
? \rightarrow \text { recurrence }\end{array}$ \\
\hline N.E.J.M. (1960) & 1 Partial gastrectomy & 1,600 & & $\begin{array}{l}\text { Little free } \\
\text { acid }\end{array}$ & & $\begin{array}{l}\text { Free acid } \\
\text { present } \\
\text { after } \\
\text { histamine }\end{array}$ & $\begin{array}{l}2 \text { months } \\
\rightarrow \text { recurrence }\end{array}$ \\
\hline Present & 1 Partial gastrectomy & $\begin{array}{l}2,640 \text { skin dose } \\
\text { to } 2,244 \text { central } \\
\text { dose }\end{array}$ & $\begin{array}{l}\text { Basal } 24 \cdot 5 \\
\mathrm{mEq} . / \mathrm{hr} .\end{array}$ & $\begin{array}{l}\text { Augmented } \\
\text { histamine } \\
24 \cdot 2 \\
\mathrm{mEq} . / \mathrm{hr} \text {. }\end{array}$ & d 0 & 0 & $\begin{array}{l}21 \text { months and } \\
\text { continuing }\end{array}$ \\
\hline
\end{tabular}

abandoned before a minimum dose of $2,500 \mathrm{r}$ has been administered.

It is interesting to speculate as to whether the acid secretory response from a Heidenhain pouch preparation following intravenous administration of the patient's pervaporated serum represented a gastrin response. The absence of a response following the injection of the same quantities of serum obtained from two duodenal ulcer subjects with basal hypersecretion pointed against a histamine, insulin, or non-specific protein effect as being responsible for the secretory response noted with our patient's serum. However, further studies are obviously necessary to determine whether the gastric secretory stimulant apparently present in pervaporated serum derived from relatively large quantities of blood shares all the properties recently attributed (Jackson, Blair, Dawson, Reed, and Watts, 1963; Hirschowitz, Schenker, and Boyett, 1963; Gregory and Tracy, 1964) to the stimulant present in the ZollingerEllison tumour itself.

\section{SUMMARY}

Another Bantu woman with a malignant ZollingerEllison syndrome is described, in whom an emer- gency gastrectomy was carried out for uncontrollable bleeding.

The value of the augmented histamine test in the diagnosis of the condition is stressed, and the histological similarity between ulcerogenic tumours of the pancreas and carcinoid briefly reviewed. The possible diagnostic value of the relatively poor reduction in the marked basal hypersecretion following anticholinergics found in the present case is considered.

Gastric radiotherapy to the gastric remnant, given because of recurrent ulceration, resulted in a prolonged remission associated with a virtual histamine-fast achlorhydria.

A serum concentrate from the patient was found to induce an acid secretory response in a dog equipped with a Heidenhain pouch, and the significance of this finding is discussed.

We would like to thank Dr. J. Burger (Medical Superintendent) and Mr. W. Schulze (senior consultant surgeon) for permission to publish the case, and Dr. G. Selzer for the pervaporation of the sera.

This study was supported by the Ben May Gastroenterology Research Fund, the Herman Bequest and South African Council for Scientific and Industrial Research. 


\section{REFERENCES}

Angervall, L., Dotevall, G., Lehmann, K. E., and Norberg, P. B. (1963). Zollinger-Ellison syndrome. Report of Case. Gastroenterology, 44, 512-518.

Bank, S., Marks, I. N., and Moshal, M. G. (1964). Unpublished data.

Burge, H. W., Gill, A. M., and Lewis, R. H. (1964). Results of vagotomy with electrical stimulation tests: an interim report. Brit. med. J., 2, 17-21.

Case Records of Massachusetts General Hospital (1960). New Engl. J. Med., 262, 1132-1139.

Chvojka, V. E. (1960). Islet-cell tumors and peptic ulcers: case report of the Zollinger-Ellison syndrome. Ann. intern. Med., 53, 1180-1195.

Espiner, E. A., and Beaven, D. W. (1962). Non-specific islet-cell tumour of the pancreas with diarrhoea. Quart. J. Med., 31, 447-471.

Gerber, B. C., and Shields, T. W. (1960). Simultaneous duodenal carcinoid and non-beta cell tumors of the pancreas. Arch. Surg., 81, 379-388.

Gregory, R. A., and Tracy, H. J. (1964). A note on the nature of the gastrin-like stimulant present in Zollinger-Ellison tumours. Gut, 5, 115-117.

Grossman, M. I., Tracy, H. J., and Gregory, R. A. (1961). ZollingerEllison syndrome in a Bantu woman with isolation of a gastrinlike substance from the primary and secondary tumors. II. Extraction of gastrin-like activity from tumors. Gastroenterology, 41, 87-91.

Hirschowitz, B. I., Schenker, S., and Boyett, J. D. (1963). A highly active gastrin secretogogue extracted from a metastasis of a Zollinger-Ellison tumor. Amer. J. dig. Dis., 8, 499-508.

Horsley, G., and Golden, B. N. (1957). Carcinoid tumors of the duodenum. Int. Abstr. Surg., 105, 417-424.

Jackson, R. H., Blair, E. L., Dawson, P. J., Reed, J. D., and Watts, W. P. T. (1963). Gastrin activity of tumour tissue in a child with the Zollinger-Ellison syndrome. Lancet, 2, 908-912.

Lemmer, K. E. (1942). Carcinoid tumors of the stomach. Surgery, 12 , 378-382.

Marks, I. N. (1961). The augmented histamine test. Editorial, Gastroenterology, 41, 599-603.
Marks, I. N., Bank, S., Louw, J. H., and Van Embden, B. H. (1962). The augmented histamine test. An analysis of 672 consecutive tests. S. Afr. med. J., 36, 807-812.

- - Moshal, M. G., and Louw, J. H. (1963). The augmented histamine test. A review of 615 cases of gastroduodenal disease. S. Afr. J. Surg., 1, 53-59.

--, Selzer, G. Louw, J. H., and Bank, S. (1961). ZollingerEllison syndrome in a Bantu woman, with isolation of a gastrin-like substance from the primary and secondary tumours I. Case Report. Gastroenterology, 41, 77-86.

MacDonald, R. A. (1956). A study of 356 carcinoids of the gastrointestinal tract. Amer. J. Med., 21, 867-878.

MacKenzie, W. C., and Norvell, S. T., Jr. (1960). Islet cell tumours and peptic ulcers. J. roy. Coll. Surg. Edinb., 5, 191-205.

Mieher, W. C. Jr., Hartsock, R. J., Geokas, M. C., Ballard, H. S., and Frame, B. (1962). Peptic ulcer as a manifestation of familial polyendocrine disease. Report of two cases occurring in sisters, with a preliminary report of eight other family members. J. Amer. med. Ass., 179, 854-858.

Oberhelman, H. A. Jr., Nelsen, T. S., and Dragstedt, L. R. (1958). Peptic ulcer associated with tumors of the pancreas. Arch. Surg., 77, 402-415.

,$- \longrightarrow$, Johnson, A. N. Jr., and Dragstedt, L. R. (1961). Ulcerogenic tumors of the duodenum. Ann. Surg., 153, 214-227.

Ricketts, W. E., Palmer, W. L., Kirsner, J. B., and Hamann, A. (1948). Radiation therapy in peptic ulcer: an analysis of results. Gastroenterology, 11, 789-806.

Sanchez, G. C., and Sommers, S. C. (1960). Peptic ulcer diathesis with a mixed adenocarcinoma of the pancreas. Ibid., 38, 467-470.

Shay, H., Chey, W. Y., Koide, S. M., and Burnett, W. E. (1962). Mechanism of the disordered physiology involved in the Zollinger-Ellison syndrome. Amer. J. dig. Dis., 7, 401-419.

Williams, E. D., and Celestin, L. R. (1962). The association of bronchial carcinoid and pluriglandular adenomatosis. Thorax, 17, 120-127.

Zollinger, R. M., and Craig, T. V. (1960). Endocrine tumors and peptic ulcer. Amer. J. Med., 29, 761-768.

- and Ellison, E. H. (1955). Primary peptic ulcerations of the jejunum associated with islet cell tumors of the pancreas. Ann. Surg., 142, 709-728.

—, Elliot, D. W., Endahl, G. L., Grant, G. N., Goswitz, J. T., and Taft, D. A. (1962). Origin of the ulcerogenic hormone in endocrine induced ulcer. Ann. Surg., 156, 570-578. 